\title{
A Microcosm Treatability Study for Evaluating Wood Mulch-Based Amendments as Electron Donors for Trichloroethene (TCE) Reductive Dechlorination
}

\author{
Edoardo Masut ${ }^{1}$, Alessandro Battaglia ${ }^{1}$, Luca Ferioli ${ }^{1}$, Anna Legnani ${ }^{1}$, Carolina Cruz Viggi ${ }^{2}$ (D, Matteo Tucci ${ }^{2}$, \\ Marco Resitano ${ }^{2}$, Alessandro Milani ${ }^{2}$, Camilla de Laurentiis ${ }^{2}$, Bruna Matturro ${ }^{2} \mathbb{D}$, Maria Letizia Di Franca ${ }^{2}$, \\ Simona Rossetti ${ }^{2}$ and Federico Aulenta ${ }^{2, *(1)}$
}

1 ERM Italia S.p.A.-Via San Gregorio 38, 20124 Milano, Italy; Edoardo.Masut@erm.com (E.M.); Alessandro.Battaglia@erm.com (A.B.); luca.ferioli@erm.com (L.F.); anna.legnani@erm.com (A.L.)

2 Water Research Institute (IRSA), National Research Council (CNR), Via Salaria km 29,300, 00015 Monterotondo, Italy; cruzviggi@irsa.cnr.it (C.C.V.); matteo.tucci@irsa.cnr.it (M.T.); resitano@irsa.cnr.it (M.R.); milani.1703418@studenti.uniroma1.it (A.M.); delaurentiis.1646496@studenti.uniroma1.it (C.d.L.); matturro@irsa.cnr.it (B.M.); marialetizia.difranca@irsa.cnr.it (M.L.D.F.); rossetti@irsa.cnr.it (S.R.)

* Correspondence: aulenta@irsa.cnr.it

\section{check for} updates

Citation: Masut, E.; Battaglia, A.; Ferioli, L.; Legnani, A.; Cruz Viggi, C.; Tucci, M.; Resitano, M.; Milani, A.; de Laurentiis, C.; Matturro, B.; et al. A Microcosm Treatability Study for Evaluating Wood Mulch-Based Amendments as Electron Donors for Trichloroethene (TCE) Reductive Dechlorination. Water 2021, 13, 1949. https://doi.org/10.3390/w13141949

Academic Editor: Simona Di Gregorio

Received: 15 June 2021

Accepted: 14 July 2021

Published: 15 July 2021

Publisher's Note: MDPI stays neutral with regard to jurisdictional claims in published maps and institutional affiliations.

Copyright: (c) 2021 by the authors. Licensee MDPI, Basel, Switzerland. This article is an open access article distributed under the terms and conditions of the Creative Commons Attribution (CC BY) license (https:// creativecommons.org/licenses/by/ $4.0 /)$

\begin{abstract}
In this study, wood mulch-based amendments were tested in a bench-scale microcosm experiment in order to assess the treatability of saturated soils and groundwater from an industrial site contaminated by chlorinated ethenes. Wood mulch was tested alone as the only electron donor in order to assess its potential for stimulating the biological reductive dechlorination. It was also tested in combination with millimetric iron filings in order to assess the ability of the additive to accelerate/improve the bioremediation process. The efficacy of the selected amendments was compared with that of unamended control microcosms. The results demonstrated that wood mulch is an effective natural and low-cost electron donor to stimulate the complete reductive dechlorination of chlorinated solvents to ethene. Being a side-product of the wood industry, mulch can be used in environmental remediation, an approach which perfectly fits the principles of circular economy and addresses the compelling needs of a sustainable and low environmental impact remediation. The efficacy of mulch was further improved by the co-presence of iron filings, which accelerated the conversion of vinyl chloride into the ethene by increasing the $\mathrm{H}_{2}$ availability rather than by catalyzing the direct abiotic dechlorination of contaminants. Chemical analyses were corroborated by biomolecular assays, which confirmed the stimulatory effect of the selected amendments on the abundance of Dehalococcoides mccartyi and related reductive dehalogenase genes. Overall, this paper further highlights the application potential and environmental sustainability of wood mulchbased amendments as low-cost electron donors for the biological treatment of chlorinated ethenes.
\end{abstract}

Keywords: groundwater bioremediation; reductive dechlorination; wood mulch; Dehalococcoides mccartyi; trichloroethene; microcosm study; iron filings

\section{Introduction}

Chlorinated aliphatic hydrocarbons are among the most common and dangerous soil and groundwater pollutants [1]. These compounds, which have been largely used as solvents, degreasing agents, and chemical feedstocks in a variety of industrial sectors, have entered the environment through accidental spills, leakage from underground storage tanks, as well as improper handling and disposal practices [2].

Chlorinated solvents, such as trichloroethene (TCE), due to the oxidized nature of the carbon atoms inferred by the chlorine substituents, are preferentially degraded via either biotic or abiotic reductive dechlorination (RD) pathways [3-5]. RD involves the sequential replacement of chlorine atoms on the alkene molecule with hydrogen atoms. In 
the case of TCE, the reaction chain involves the sequential formation of dichloroethene (DCE), vinyl chloride (VC), and finally, the non-toxic ethene (ETH) [6]. Notably, an incomplete dechlorination with VC accumulating as the end product of the reaction may be extremely critical from an environmental and toxicological standpoint because VC is far more toxic than its parent compounds, as it has been identified as a known human carcinogen. Thus, complete RD is essential to all remediation practices, either abiotic or biotic.

The abiotic RD is typically driven by reducing chemical agents, such as zero valent iron or iron sulfide [7-10]. By contrast, the biotic RD process is catalyzed by different types of bacteria, often referred to as organohalide respiring bacteria (OHRB). These bacteria use the chlorinated hydrocarbons as respiratory electron acceptors in their energy metabolism, while typically using molecular hydrogen as electron donor [11-13]. Among OHRB, Dehalococcoides mccartyi is the only microorganism capable of catalyzing the RD of TCE to ETH, and therefore, its presence at a contaminated site is essential to the successful implementation of a bioremediation process based on RD processes [14-17]. Indeed, other OHRB, such as Geobacter, Sulfurospirillum, Desulfitobacterium, and Dehalobacter, can partially dechlorinate TCE only to cis-DCE [13]. The reductive dechlorination processes performed by microorganisms are catalyzed by enzymes called reductive dehalogenases (RDases), which are encoded by the RDase subunit A gene (rdhA) [18]. A few rdhA genes that act on chlorinated ethenes have been functionally characterized, such as the tceA catalyzing the reduction of TCE to VC [19], the vcrA and bvcA catalyzing the reduction of DCEs, and VC to ETH [20,21].

From an applicative standpoint, different strategies can be employed to implement the biotic or abiotic reductive dechlorination process. Among them, an interesting approach involves the introduction of slow-release, long-lasting, organic electron donors into the subsurface (e.g., within permeable reactive barriers) to stimulate naturally occurring (or ad hoc bioaugmented) OHRB using the chlorinated compounds as electron acceptors [22-24]. In the subsurface, these organic substrates are slowly degraded under anaerobic conditions by naturally occurring microbial communities with concomitant generation of hydrogen, which is then used by OHRB and/or other hydrogenophilic microorganisms, such as methanogens $[25,26]$. Among slow-release electron donors, wood mulch is particularly attractive since it is a low-cost and often a locally sourced side product of the wood industry, and its utilization can improve the economic viability, circularity, and environmental sustainability of a remediation project [27-29]. Mulch is the shredded and chipped pieces of trees or shrubs, mainly containing cellulose and lignin. Under anaerobic conditions, mulch is slowly hydrolyzed, and the resulting monomers are fermented into a broad spectrum of products, including alcohols, fatty acids, hydrogen, carbon dioxide, and methane [30]. Importantly, mulch-derived fermentation products can support the metabolism of various OHRB. In addition to serving as an electron donor, mulch is also a good support material for biofilm formation and has noticeable capacity to adsorb chlorinated compounds [27]. Therefore, mulch has the potential to allow an effective co-localization of OHRB, the electron donor, and the electron acceptor, which thereby facilitates an effective bioremediation process. To date, wood mulch has been used as an electron donor for chlorinated solvents RD in numerous laboratory and field applications, although the complete transformation of contaminants into harmless non chlorinated end products has been rarely reported [31,32]. Based on these considerations, the aim of the present study was to evaluate the viability of using mulch-based amendments as sustainable electron donors for the reductive dechlorination of TCE. Furthermore, the combination of mulch with a chemical reducing agents (i.e., iron filings) was explored as a strategy to improve the bioremediation efficacy by exploiting the synergy of biotic and abiotic processes. 


\section{Materials and Methods}

\subsection{Microcosm Setup, Monitoring Protocols, and Analytical Procedures}

Microcosms were prepared by using soil and groundwater samples taken within the contamination source of a chlorinated solvent-contaminated site located in northeast Italy. In particular, one set of microcosms (hereafter named "BS") was set up using soil and groundwater collected from a shallow aquifer, whereas another set (hereafter named "BD") was set up using material collected from a deeper (low conductivity) aquitard. In addition to chlorinated solvents, the groundwater also contained sulfate $(14 \pm 4 \mathrm{mg} / \mathrm{L}$ and $25 \pm 4 \mathrm{mg} / \mathrm{L}$ in BS and BD microcosms, respectively) and low levels $(<1 \mathrm{mg} / \mathrm{L})$ of nitrate. Microcosms, prepared in $250 \mathrm{~mL}$ anaerobic serum bottles sealed with Teflon-faced butyl rubber stoppers, contained $50 \mathrm{~g}$ of wet soil and $100 \mathrm{~mL}$ of groundwater.

Upon preparation, the serum bottles were purged with a $\mathrm{N}_{2}: \mathrm{CO}_{2}(70: 30 \mathrm{v} / \mathrm{v})$ gas mixture, along with $5 \mathrm{~mL}$ of an anoxic bicarbonate solution $(10 \% w / v)$ to buffer the $\mathrm{pH}$ around neutrality and $0.5 \mathrm{~mL}$ of a dechlorinating inoculum containing D. mccartyi. They were finally spiked with TCE (to obtain an initial concentration of approx. $10 \mathrm{mg} / \mathrm{L}$ ).

Three different treatment conditions were established, depending on the applied electron donor (Figure 1). The "unamended control" did not receive any exogenous electron donor, in addition to what was already present in the groundwater and in the soil. The "Mulch" treatment contained $12.5 \mathrm{~g}$ of finely shredded pine and spruce mulch and $12.5 \mathrm{~g}$ of washed river gravel $(2-6 \mathrm{~mm})$; the "Mulch + Iron filings" treatment differed from the "Mulch" treatment for the additional presence of $3 \mathrm{~g}$ of iron filings as a reducing agent.

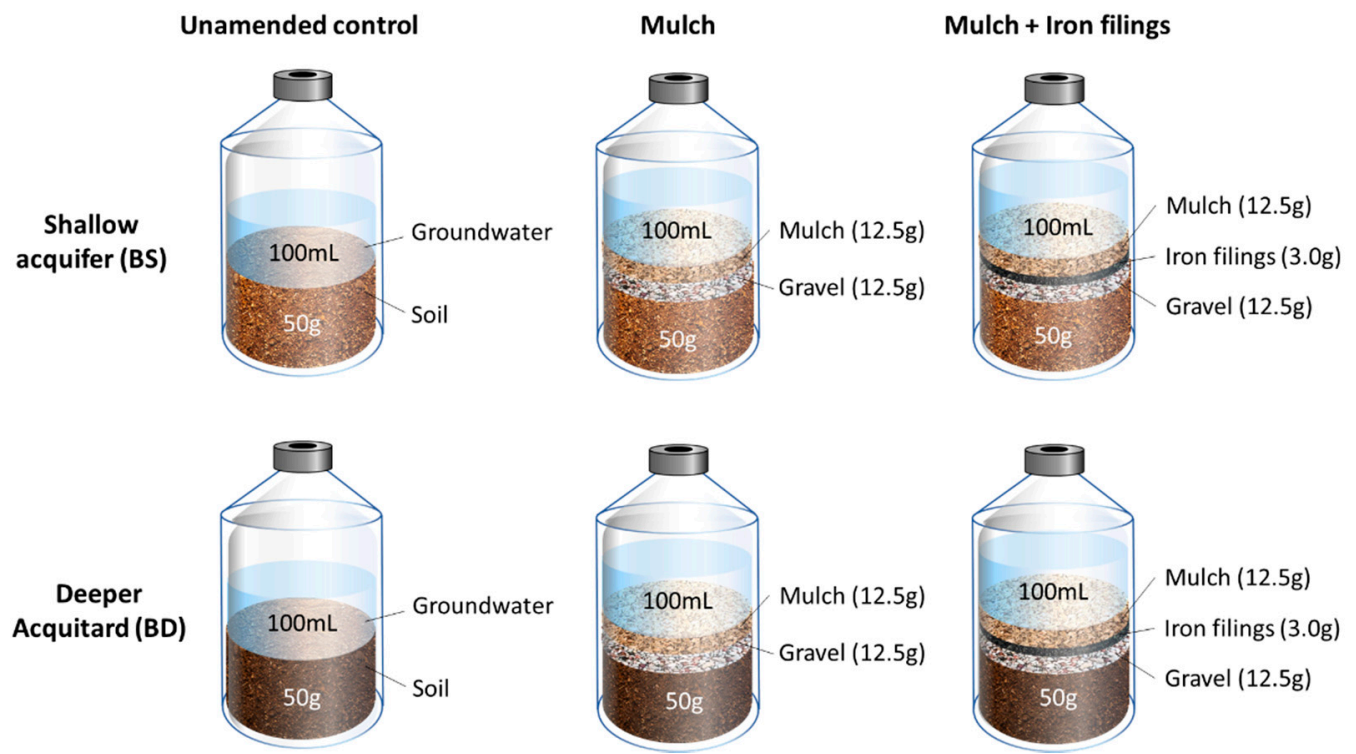

Figure 1. Scheme of the different treatments used for the microcosms. The depicted layered distribution of amendments within the serum bottles is for illustrative purposes only.

Duplicate bottles were prepared for each treatment conditions to ensure reproducibility. Microcosms were incubated statically, in the dark, at room temperature (i.e., $20-25{ }^{\circ} \mathrm{C}$ ).

Throughout the incubation period, all the microcosms were periodically analyzed for the chlorinated solvents, ethene, methane, anions, iron, manganese, $\mathrm{pH}$, and redox potential, as previously described [26,33]. In particular, volatile compounds were quantified in $50 \mu \mathrm{L}$ headspace samples by using gas chromatography with a flame ionization detector, whereas anions were quantified in filtered $(0.22 \mu \mathrm{m})$ liquid samples by ion chromatography with an electrical conductivity detector. The dissolved iron species $\left(\mathrm{Fe}^{2+}\right.$, $\left.\mathrm{Fe}^{3+}\right)$ and total manganese were also quantified in filtered $(0.22 \mu \mathrm{m})$ liquid samples using commercial spectrophotometric kits (Merk, Darmstadt, Germany). The redox potential 
and the $\mathrm{pH}$ were analyzed in unfiltered samples using specific electrodes (Mettler Toledo, Greifensee, Switzerland).

\subsection{Quantification of D. mccartyi and Rdha Genes}

Samples for biomolecular analysis ( $2 \mathrm{~mL}$ of slurry) were collected at the end of the incubation period. The slurry was filtered on polycarbonate filters (pore size $0.22 \mu \mathrm{m}, 47 \mathrm{~mm}$ diameter, Nuclepore) to harvest the biomass. DNA was extracted directly from the filters by PowerSoil DNA extraction kit (Qiagen, Milano, Italy) following the manufacturer's instructions. Purified DNA from each sample was eluted in $70 \mu \mathrm{L}$ sterile Milli-Q and stored at $-20^{\circ} \mathrm{C}$. The presence and abundance of D. mccartyi and of rdhA genes, including tceA, bvcA and vcrA, were determined by real-time polymerase chain reaction (qPCR) via absolute quantification assays. The primers used for the qPCR assay are described in a previous work [34]. All qPCR probes were labeled 6-carboxyfluoresceine as the $5^{\prime}$ end reporter fluorophore and $N, N, N^{\prime \prime}, N^{\prime \prime}$-tetramethyl-6-carboxyrhodamine as $3^{\prime}$ end quencher. Each reaction was performed in $20 \mu \mathrm{L}$ total volume with SsoAdvancedTM Universal Probes Supermix (Bio-rad, Milano, Italy). Purified PCR long amplicons were used as standards for the absolute quantification for each targeted gene [35].

\section{Results}

\subsection{Time Course of $R D$}

The time course of TCE (spiked into the microcosms) and cis-DCE (deriving from the soil and/or groundwater) dechlorination in the different microcosms is shown in Figure 2.

Slow dechlorination of TCE to cis-DCE, possibly driven by naturally occurring electron donors in the groundwater or soil, was observed in the "Unamended Control BS". Conversely, negligible dechlorination was observed in the corresponding microcosms setup using groundwater and soil from the deeper aquitard (i.e., "Unamended Control BD"). The presence of mulch remarkably accelerated the reductive dechlorination process, clearly indicating that the microbial dechlorinating activity was rate-limited by the electron donor availability. Both in BS and BD microcosms, the complete reductive of TCE and cis-DCE to ethene, was observed in nearly 90 days.

Notably, the dechlorination process proceeded via intermediate accumulation of substantial amounts (nearly $50 \%$ of the initial chloroethenes, on a molar basis) of the harmful intermediate VC, which suggests that VC conversion into ethene (ETH) was, as typically reported [36], the slowest step of the overall reductive dechlorination process in D. mccartyi.

The presence of mulch also stimulated an active methanogenic activity, which proceeded simultaneously to the dechlorination process, as well as the complete reduction of sulfate. The enhanced electron donor availability resulted in the release of only small amounts $\left(<10 \mathrm{mg} / \mathrm{L}\right.$ ) of $\mathrm{Fe}^{2+}$ (and negligible amounts of total $\mathrm{Mn}$ ) into the groundwater, suggesting that iron (and manganese) minerals were likely not major constituents of the soils used to set up the microcosms. 

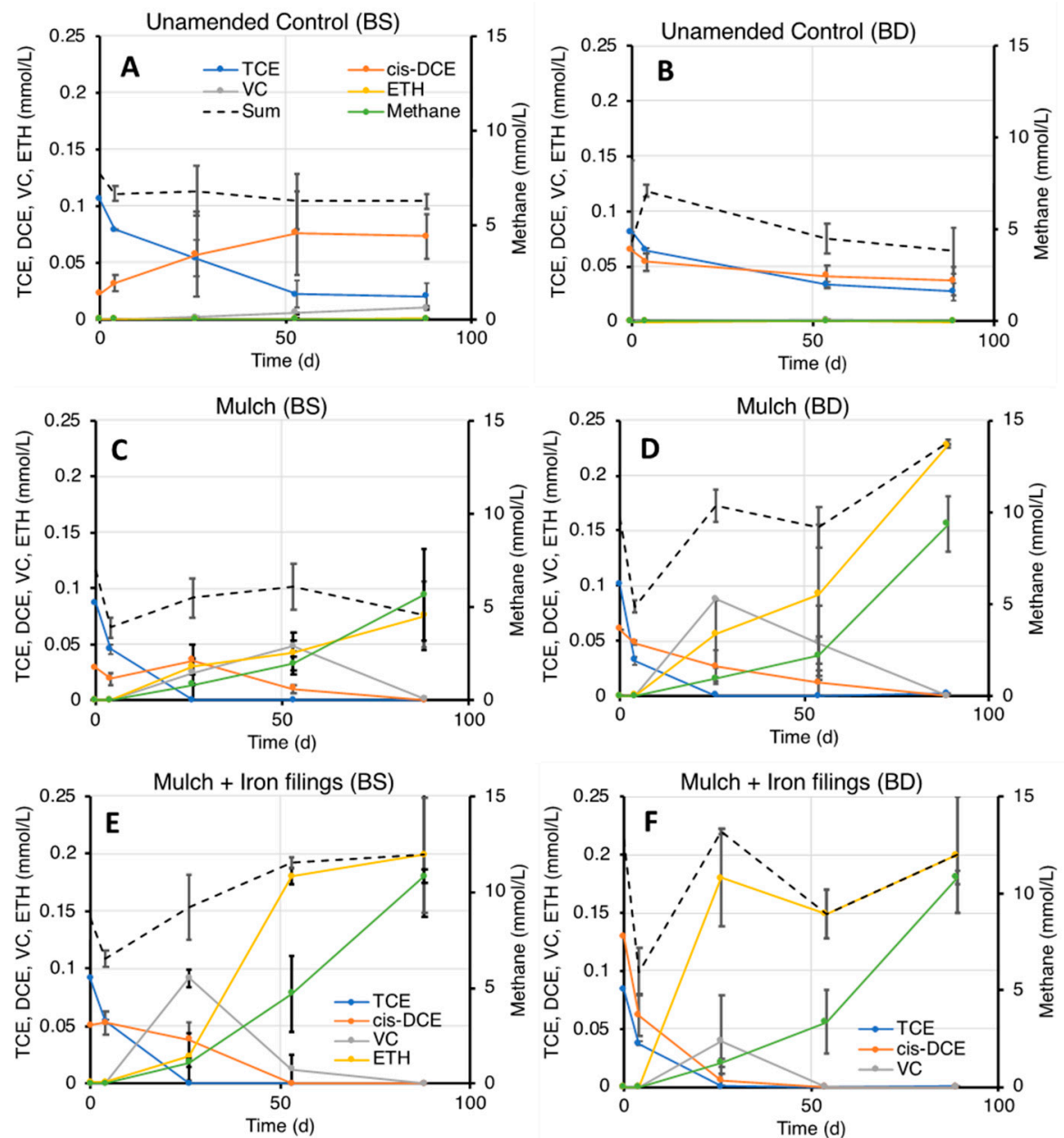

Figure 2. Time course of TCE and cis-DCE dechlorination in BS and BD microcosms, under different electron donor conditions (mean values \pm standard error of duplicate microcosms): (A,B) no electron donors; $(\mathbf{C}, \mathbf{D})$ Shredded pine and spruce mulch; $(\mathbf{E}, \mathbf{F})$ : Shredded pine and spruce mulch and iron filings.

\subsection{Impact of Iron Filings on the Kinetics of Dechlorination and Methanogenesis}

The simultaneous presence of mulch and iron filings had a marked effect on the kinetics of the reductive dechlorination process and in particular, on the reductive dechlorination of cis-DCE and VC, which were substantially accelerated both in BS and BD microcosms.

Figure 3 compares, for the different amendment conditions, the observed maximum rates of VC dechlorination (as estimated from the measured ETH formation), which is the most critical step of the entire dechlorination process due to the relevant health risks associated with the persistence of this harmful intermediate.

Interestingly, in the BS microcosm, the rate of ethene formation in the presence of mulch and iron filings was more than 10 times higher than in the corresponding microcosm lacking the iron filings. The enhancement effect was apparently lower (nearly 1.4-fold) in the BD microcosms. It is worth noting that the iron filings also had a marked effect on the kinetics of methane production, which was enhanced by a factor of 2.5 in BS microcosms and 1.7 in BD microcosms.

At the end of the incubation period, all the mulch and mulch and iron filingsamended microcosms contained a soluble chemical oxygen demand concentration exceeding $1000 \mathrm{mg} / \mathrm{L}$, which confirms that mulch, upon hydrolysis and (bio)degradation, served as a long-lasting carbon source and electron donor. 

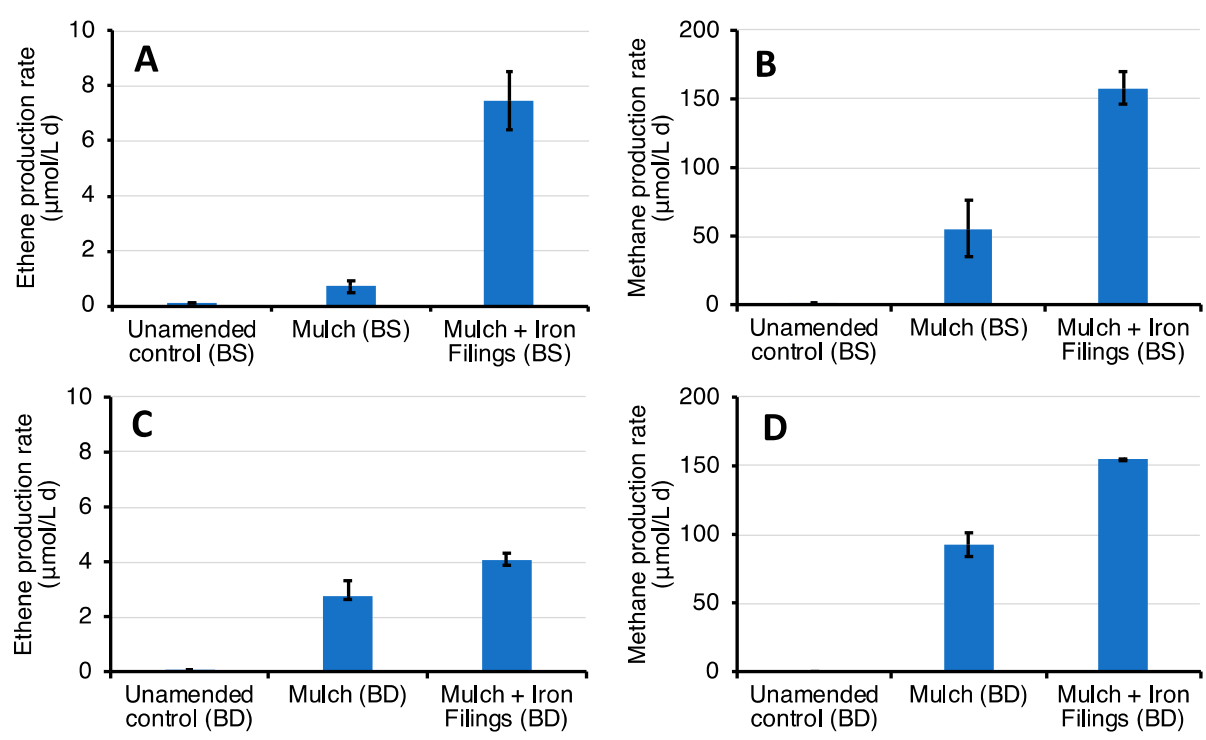

Figure 3. Maximum ethene $(\mathbf{A}-\mathbf{C})$ and methane $(\mathbf{B}-\mathbf{D})$ production rate (mean values \pm standard error of duplicate microcosms) in BS and BD microcosms under different electron donor conditions.

Overall, these findings suggest that the iron filings accelerated the reductive dechlorination, as well as methanogenesis, by providing, upon reaction with water (i.e., corrosion), some additional, ready-to-use, $\mathrm{H}_{2}$. Indeed, previous studies have noted that hydrogenophilic methanogenesis and the last steps of chloroethenes dechlorination have a relatively low affinity for hydrogen (i.e., high half-saturation constants for $\mathrm{H}_{2}$ ), thus requiring relatively higher $\mathrm{H}_{2}$ levels to proceed at their maximum rates [37,38].

To prove this case and quantify the capability of the used iron filings to generate $\mathrm{H}_{2}$ via abiotic iron oxidation (i.e., corrosion), additional batch experiments were conducted, using increasing amounts of iron filings (up to $3 \mathrm{~g}$ ) which were added to serum bottles $(120 \mathrm{~mL})$ containing anaerobic mineral medium $(\mathrm{pH}=7)$. Production of $\mathrm{H}_{2}$ commenced from the beginning of the tests and continued at a constant rate for the whole duration of the experiment (26 days) (Figure 3 ). Notably, the rate of hydrogen production was linearly dependent on the applied iron filings concentration (inset of Figure 4).

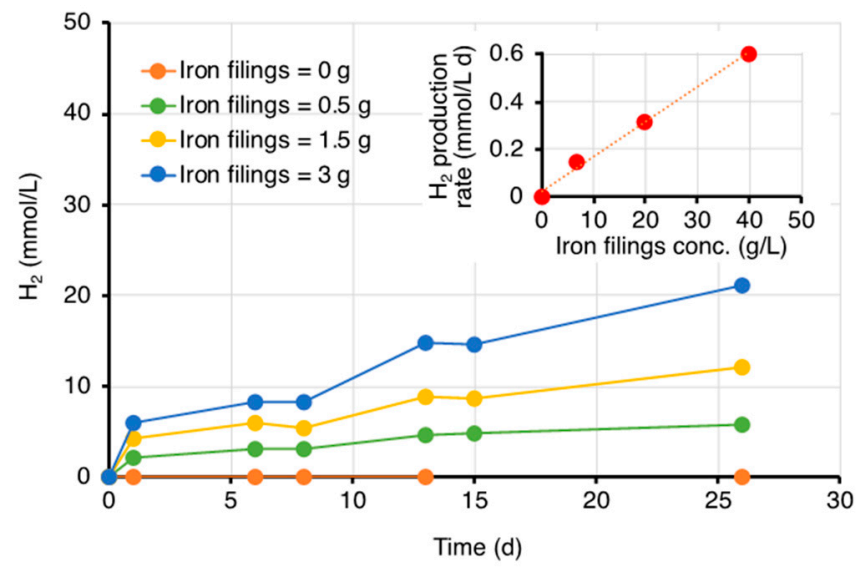

Figure 4. Time course of abiotic hydrogen evolution in anaerobic mineral medium $(\mathrm{pH}=7)$ in the presence of different amounts of iron filings. Inset: abiotic hydrogen evolution rate as a function of the amount of added iron filings.

In the live microcosms, the enhancement in the rate of methane production and dechlorination due to the presence of iron filings (based on data reported in Figure 3) was, at maximum (in microcosms BS), of $100 \mu \mathrm{mol} / \mathrm{L} \mathrm{d}$ and $7 \mu \mathrm{mol} / \mathrm{L} \mathrm{d}$, respectively. Assuming 
this enhancement was completely driven by $\mathrm{H}_{2}$, this would have required a corresponding increase in $\mathrm{H}_{2}$ availability of approximately $0.4 \mathrm{mmol} / \mathrm{L} \mathrm{d}$. Considering that in the BS and $\mathrm{BD}$ microcosms the applied concentration of iron filings was approximately $30 \mathrm{~g} / \mathrm{L}$, it is apparent that the rate of abiotic $\mathrm{H}_{2}$ evolution perfectly matched with the observed enhancement of $\mathrm{H}_{2}$ utilization.

\subsection{Biomolecular Analyses}

The stimulatory effect of mulch and mulch and iron filings on the reductive dechlorination process was confirmed by the results of the biomolecular analyses. Indeed, in all amended microcosms, at the end of the incubation period the abundance of D. mccartyi and related rdhA genes was more than two orders of magnitude higher than in the unamended controls (Figure 5). As confirmed by the chemical analyses, the effect of iron filings was more evident in microcosms BS (Figure 5A) in which the concentration of D. mccartyi and related dehalogenases was higher $(p<0.005)$ in "Mulch + Iron Filings" microcosms than in "Mulch" microcosms. By contrast, in BD microcosms in which the apparent effect of the iron filings on the kinetics of the dechlorination process was less marked, no statistically relevant differences were noticed in the concentration of D. mccartyi and related rdhA genes among "Mulch" and "Mulch + Iron Filings" treatments (Figure 5B). Overall, the observed correlation between $\mathrm{VC}$ dechlorination and biomolecular parameters in the different microcosms provides an additional line of evidence that iron filings enhanced the $\mathrm{RD}$ process by stimulating the microbial activity (through $\mathrm{H}_{2}$ evolution) rather than by catalyzing the direct abiotic dechlorination of contaminants.
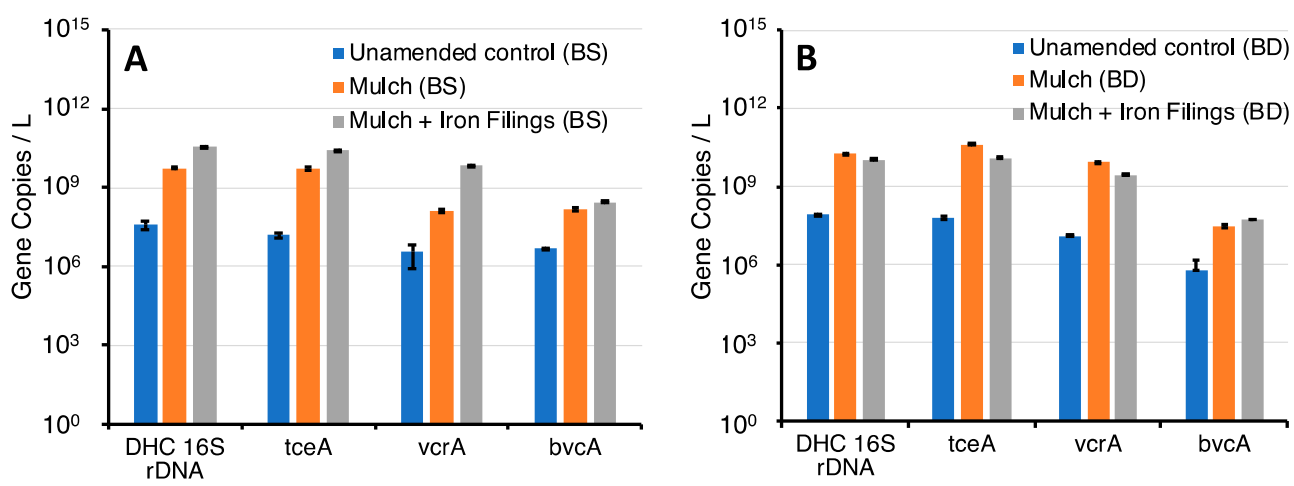

Figure 5. Abundance of Dehalococcoides mccartyi $16 \mathrm{~S}$ rDNA, tceA, vcrA, and bvcA genes in BS (A) and $\mathrm{BD}$ (B) microcosms (mean values \pm standard error of duplicate microcosms) under different electron donor conditions.

\section{Conclusions}

This study demonstrates that mulch is an effective natural and low-cost electron donor to stimulate the complete reductive dechlorination of chlorinated solvents, such as TCE and cis-DCE to ethene. Being a side-product of the wood industry, mulch can be used in environmental remediation, with this approach perfectly fitting the principles of circular economy and addressing the compelling needs of a sustainable and low environmental impact remediation. Interestingly, the efficacy of mulch could be further boosted by the co-presence of iron filings, with these latter accelerating the more sluggish steps of the dechlorination process, such as the conversion of VC into the harmless ethene.

Further studies are now needed to identify the optimal operational conditions and application criteria of a mulch-barrier and confirm the results obtained in this study under more representative environmental conditions. 
Author Contributions: Conceptualization, E.M., A.B., L.F., A.L., S.R., F.A.; methodology, E.M., A.B., L.F., A.L., M.T., C.C.V., B.M., S.R., F.A.; Investigation, M.R., A.M., C.d.L., M.L.D.F., supervision, B.M., F.A., writing-original draft preparation, E.M., A.B., L.F., A.L., F.A. All authors have read and agreed to the published version of the manuscript.

Funding: This research received no external funding.

Institutional Review Board Statement: Not applicable.

Informed Consent Statement: Not applicable.

Data Availability Statement: Not applicable.

Conflicts of Interest: The authors declare no conflict of interest.

\section{References}

1. Aulenta, F.; Di Tomassi, C.; Cupo, C.; Papini, M.P.; Majone, M. Influence of hydrogen on the reductive dechlorination of tetrachloroethene (PCE) to ethene in a methanogenic biofilm reactor: Role of mass transport phenomena. J. Chem. Technol. Biotechnol. 2006, 81, 1520-1529. [CrossRef]

2. Aulenta, F.; Fuoco, M.; Canosa, A.; Papini, M.P.; Majone, M. Use of poly- $\beta$-hydroxy-butyrate as a slow-release electron donor for the microbial reductive dechlorination of TCE. Water Sci. Technol. 2008, 57, 921-925. [CrossRef]

3. Aulenta, F.; Majone, M.; Tandoi, V. Enhanced anaerobic bioremediation of chlorinated solvents: Environmental factors influencing microbial activity and their relevance under field conditions. J. Chem. Technol. Biotechnol. 2006, 81, 1463-1474. [CrossRef]

4. Aulenta, F.; Pera, A.; Rossetti, S.; Petrangeli Papini, M.; Majone, M. Relevance of side reactions in anaerobic reductive dechlorination microcosms amended with different electron donors. Water Res. 2007, 41, 27-38. [CrossRef]

5. Aulenta, F.; Potalivo, M.; Majone, M.; Papini, M.P.; Tandoi, V. Anaerobic Bioremediation of Groundwater Containing a Mixture of 1,1,2,2-Tetrachloroethane and Chloroethenes. Biodegradation 2006, 17, 193-206. [CrossRef]

6. Borden, R.C.; Rodriguez, B.X. Evaluation of Slow Release Substrates for Anaerobic Bioremediation. Bioremediat. J. 2006, 10, 59-69. [CrossRef]

7. Chang, H.L.; Alvarez-Cohen, L. Biodegradation of individual and multiple chlorinated aliphatic hydrocarbons by methaneoxidizing cultures. Appl. Environ. Microbiol. 1996, 62, 3371-3377. [CrossRef]

8. Evangelista de Duffard, A.M.; Duffard, R. Behavioral toxicology, risk assessment, and chlorinated hydrocarbons. Environ. Health Perspect. 1996, 104, 353-360. [CrossRef] [PubMed]

9. Hug, L.A.; Maphosa, F.; Leys, D.; Löffler, F.E.; Smidt, H.; Edwards, E.A.; Adrian, L. Overview of organohalide-respiring bacteria and a proposal for a classification system for reductive dehalogenases. Philos. Trans. R. Soc. B Biol. Sci. 2013, 368, 20120322. [CrossRef] [PubMed]

10. Jugder, B.-E.; Ertan, H.; Bohl, S.; Lee, M.; Marquis, C.P.; Manefield, M. Organohalide Respiring Bacteria and Reductive Dehalogenases: Key Tools in Organohalide Bioremediation. Front. Microbiol. 2016, 7, 249. [CrossRef]

11. Kennedy, L.G.; Everett, J.W. Field application of biogeochemical reductive dechlorination by permeable reactive barrier. Int. J. Environ. Waste Manag. 2014, 14, 323. [CrossRef]

12. Lee, W.; Batchelor, B. Abiotic Reductive Dechlorination of Chlorinated Ethylenes by Iron-Bearing Soil Minerals. 2. Green Rust. Environ. Sci. Technol. 2002, 36, 5348-5354. [CrossRef]

13. Lee, W.; Batchelor, B. Abiotic Reductive Dechlorination of Chlorinated Ethylenes by Iron-Bearing Soil Minerals. 1. Pyrite and Magnetite. Environ. Sci. Technol. 2002, 36, 5147-5154. [CrossRef] [PubMed]

14. Löffler, F.E.; Yan, J.; Ritalahti, K.M.; Adrian, L.; Edwards, E.A.; Konstantinidis, K.T.; Müller, J.A.; Fullerton, H.; Zinder, S.H.; Spormann, A.M. Bacterial class, Dehalococcoidia classis nov., order Dehalococcoidales ord. nov. and family Dehalococcoidaceae fam. nov., within the phylum Chloroflexi. Int. J. Syst. Evol. Microbiol. 2013, 63, 625-635. [CrossRef]

15. Magnuson, J.K.; Romine, M.F.; Burris, D.R.; Kingsley, M.T. Trichloroethene Reductive Dehalogenase from Dehalococcoides ethenogenes: Sequence of tceA and Substrate Range Characterization. Appl. Environ. Microbiol. 2000, 66, 5141-5147. [CrossRef]

16. Majone, M.; Verdini, R.; Aulenta, F.; Rossetti, S.; Tandoi, V.; Kalogerakis, N.; Agathos, S.; Puig, S.; Zanaroli, G.; Fava, F. In situ groundwater and sediment bioremediation: Barriers and perspectives at European contaminated sites. New Biotechnol. 2015, 32, 133-146. [CrossRef]

17. McCarty, P.L. In situ bioremediation of chlorinated solvents. Curr. Opin. Biotechnol. 1993, 4, 323-330. [CrossRef]

18. Molenda, O.; Puentes Jácome, L.A.; Cao, X.; Nesbø, C.L.; Tang, S.; Morson, N.; Patron, J.; Lomheim, L.; Wishart, D.S.; Edwards, E.A. Insights into origins and function of the unexplored majority of the reductive dehalogenase gene family as a result of genome assembly and ortholog group classification. Environ. Sci. Process. Impacts 2020, 22, 663-678. [CrossRef] [PubMed]

19. Müller, J.A.; Rosner, B.M.; von Abendroth, G.; Meshulam-Simon, G.; McCarty, P.L.; Spormann, A.M. Molecular Identification of the Catabolic Vinyl Chloride Reductase from Dehalococcoides sp. Strain VS and Its Environmental Distribution. Appl. Environ. Microbiol. 2004, 70, 4880-4888. [CrossRef] [PubMed] 
20. Niño de Guzmán, G.T.; Hapeman, C.J.; Millner, P.D.; McConnell, L.L.; Jackson, D.; Kindig, D.; Torrents, A. Using a high-organic matter biowall to treat a trichloroethylene plume at the Beaver Dam Road landfill. Environ. Sci. Pollut. Res. 2018, 25, 8735-8746. [CrossRef]

21. Pérez-de-Mora, A.; Lacourt, A.; McMaster, M.L.; Liang, X.; Dworatzek, S.M.; Edwards, E.A. Chlorinated Electron Acceptor Abundance Drives Selection of Dehalococcoides mccartyi (D. mccartyi) Strains in Dechlorinating Enrichment Cultures and Groundwater Environments. Front. Microbiol. 2018, 9, 812. [CrossRef]

22. Smatlak, C.R.; Gossett, J.M.; Zinder, S.H. Comparative Kinetics of Hydrogen Utilization for Reductive Dechlorination of Tetrachloroethene and Methanogenesis in an Anaerobic Enrichment Culture. Environ. Sci. Technol. 1996, 30, 2850-2858. [CrossRef]

23. Ritalahti, K.M.; Amos, B.K.; Sung, Y.; Wu, Q.; Koenigsberg, S.S.; Löffler, F.E. Quantitative PCR Targeting 16S rRNA and Reductive Dehalogenase Genes Simultaneously Monitors Multiple Dehalococcoides Strains. Appl. Environ. Microbiol. 2006, 72, $2765-2774$. [CrossRef] [PubMed]

24. Rosner, D.; Markowitz, G. Persistent pollutants: A brief history of the discovery of the widespread toxicity of chlorinated hydrocarbons. Environ. Res. 2013, 120, 126-133. [CrossRef]

25. Schaefer, C.E.; Ho, P.; Berns, E.; Werth, C. Mechanisms for Abiotic Dechlorination of Trichloroethene by Ferrous Minerals under Oxic and Anoxic Conditions in Natural Sediments. Environ. Sci. Technol. 2018, 52, 13747-13755. [CrossRef] [PubMed]

26. Seidel, K.; Kühnert, J.; Adrian, L. The Complexome of Dehalococcoides mccartyi Reveals Its Organohalide Respiration-Complex Is Modular. Front. Microbiol. 2018, 9, 1130. [CrossRef] [PubMed]

27. Shen, H.; Adair, C.; Wilson, J.T. Long-Term Capacity of Plant Mulch to Remediate Trichloroethylene in Groundwater. J. Environ. Eng. 2010, 136, 1054-1062. [CrossRef]

28. Shen, H.; Wilson, J.T. Trichloroethylene Removal from Groundwater in Flow-Through Columns Simulating a Permeable Reactive Barrier Constructed with Plant Mulch. Environ. Sci. Technol. 2007, 41, 4077-4083. [CrossRef]

29. Suarez, M.P.; Rifai, H.S. Biodegradation Rates for Fuel Hydrocarbons and Chlorinated Solvents in Groundwater. Bioremediat. J. 1999, 3, 337-362. [CrossRef]

30. Tang, S.; Chan, W.W.M.; Fletcher, K.E.; Seifert, J.; Liang, X.; Löffler, F.E.; Edwards, E.A.; Adrian, L. Functional Characterization of Reductive Dehalogenases by Using Blue Native Polyacrylamide Gel Electrophoresis. Appl. Environ. Microbiol. 2013, 79, 974-981. [CrossRef]

31. Tobiszewski, M.; Namieśnik, J. Abiotic degradation of chlorinated ethanes and ethenes in water. Environ. Sci. Pollut. Res. 2012, 19, 1994-2006. [CrossRef] [PubMed]

32. Walker, K.L.; McGuire, T.M.; Adamson, D.T.; Anderson, R.H. Long-Term Evaluation of Mulch Biowall Performance to Treat Chlorinated Solvents. Groundw. Monit. Remediat. 2020, 40, 35-46. [CrossRef]

33. Wang, S.; Qiu, L.; Liu, X.; Xu, G.; Siegert, M.; Lu, Q.; Juneau, P.; Yu, L.; Liang, D.; He, Z.; et al. Electron transport chains in organohalide-respiring bacteria and bioremediation implications. Biotechnol. Adv. 2018, 36, 1194-1206. [CrossRef]

34. Matturro, B.; Heavner, G.L.; Richardson, R.E.; Rossetti, S. Quantitative estimation of Dehalococcoides mccartyi at laboratory and field scale: Comparative study between CARD-FISH and Real Time PCR. J. Microbiol. Methods 2013, 93, 127-133. [CrossRef] [PubMed]

35. Wei, Z.; Seo, Y. Trichloroethylene (TCE) adsorption using sustainable organic mulch. J. Hazard. Mater. 2010, 181, 147-153. [CrossRef] [PubMed]

36. Yan, J.; Wang, J.; Villalobos Solis, M.I.; Jin, H.; Chourey, K.; Li, X.; Yang, Y.; Yin, Y.; Hettich, R.L.; Löffler, F.E. Respiratory Vinyl Chloride Reductive Dechlorination to Ethene in TceA-Expressing Dehalococcoides mccartyi. Environ. Sci. Technol. 2021, 55, 4831-4841. [CrossRef]

37. Yan, J.; Yang, Y.; Li, X.; Löffler, F.E. Complete Genome Sequence of Dehalococcoides mccartyi Strain FL2, a Trichloroethene-Respiring Anaerobe Isolated from Pristine Freshwater Sediment. Microbiol. Resour. Announc. 2019, 8, e00558. [CrossRef]

38. Yu, S.; Semprini, L. Enhanced reductive dechlorination of PCE DNAPL with TBOS as a slow-release electron donor. J. Hazard. Mater. 2009, 167, 97-104. [CrossRef] [PubMed] 